Note

\section{Production of DNA-breaking Substance after Treatment of Monophenols with Sodium Nitrite and then with Dimethyl Sulfoxide}

\author{
Koji Yamada, Hiroki Murakami, \\ Katsushi Yasumura, \\ Sanetaka Shirahata,* \\ Kazuki SHINOHARA** \\ and Hirohisa Omura
}

Department of Food Science and Technology, Faculty of Agriculture, Kyushu University 46-09, Higashi-ku, Fukuoka 812, Japan

Received June 27, 1986

Most mutagenic, carcinogenic, and carcinostatic substances show DNA-breaking activity in vitro. Some of them induce DNA breakage in cultured mammalian cells. ${ }^{1 \sim 4)}$ To clarify the mechanism of spontaneous carcinogenesis, it is important to screen DNA-breaking substances in the environment. We have studied DNA breakage by phenyl compounds and showed that polyphenols, aminophenols, and phenylenediamines had in vitro DNA-breaking activity, but monophenols had not. ${ }^{1)}$ We studied here the DNA-breaking activity of monophenols and iodophenols, including thyroid hormones. Such phenyl compounds react with sodium nitrite to give nitrophenols ${ }^{5)}$ and nitrosophenols. ${ }^{6)}$ Thus, the effects of nitrite treatment on the DNA-breaking activity of phenyl compounds was also examined.

Monoiodotyrosine (MIT), diiodotyrosine (DIT), triiodothyroine $\left(\mathrm{T}_{3}\right)$, and thyroxine $\left(\mathrm{T}_{4}\right)$ were obtained from Nakarai Chemicals Ltd. Other chemicals were obtained from Wako Pure Chemicals. Tyrosine, thyronine, and the above iodophenols were dissolved in dimethyl sulfoxide (DMSO) and used in our DNA-breaking reaction. The reaction mixture for detection of DNA-breaking activity $(80 \mu \mathrm{l})$ was composed of $30 \mu \mathrm{g}$ of $\lambda$ phage DNA $\left(3.2 \times 10^{7}\right.$ daltons, Miles Co., Ltd.), $250 \mu \mathrm{M} \mathrm{CuSO}_{4}, 250 \mu \mathrm{m}$ phenyl compounds, and $0.1 \mathrm{~m}$ sodium phosphate buffer ( $\mathrm{pH}$ 6.7). After incubating at $37^{\circ} \mathrm{C}$ for $6 \mathrm{hr}$, the reaction mixtures were electrophoresed on $0.7 \%$ agarose gel, as described previously. ${ }^{2)}$ The strength of DNA-breaking activity is expressed in the tables by the number of $(+)$ symbols; compounds having no activity $(-)$, those giving DNA fragments over $4 \times 10^{6}$ daltons $(+)$, and those giving fragments between $0.6 \sim 4 \times 10^{6}$ daltons $(++)$.

As summarised in Table I, none of the monophenols or iodophenols had DNA-breaking activity. This indicates that the $o$-iodo group has no effect on the DNA-breaking activity of monophenols. To discover the effects of nitro or nitroso group on the DNA-breaking activity of phenyl compounds, monophenols and iodophenols were reacted with sodium nitrite. Phenyl compounds dissolved in $\mathrm{AcOH}(10 \mathrm{~mm})$ were mixed with the same volume of $10 \mathrm{~mm}$ sodium nitrite aqueous solution and incubated at $37^{\circ} \mathrm{C}$. UV and visible spectra of the reaction mixtures were registered every hour with a Hitachi 200-10 Electrophotometer. Each reaction mixture gave a new peak in the visible region, at $360 \mathrm{~nm}$ in tyrosine derivatives, at $375 \mathrm{~nm}$ in thyronine, at $395 \mathrm{~nm}$ in $T_{3}$, and at $410 \mathrm{~nm}$ in $\mathrm{T}_{4}$ (Fig. 1). The absorbance at the maximum wavelength in each compound increased with reaction time and ceased to increase within $5 \mathrm{hr}$. Thus, we used a nitrite treatment of $6 \mathrm{hr}$ at $37^{\circ} \mathrm{C}$ thereafter.

The reaction mixtures were dried under a vacuum, dissolved in DMSO, and used in the DNA-breaking reaction. The reaction mixtures contained $250 \mu \mathrm{M}$ phenyl groups. The nitrite-treated phenols had no DNA-breaking

TABle I. EFfects of Sodium Nitrite AND DMSO Treatments ON THE DNA-BREAKING ACTIVITY OF MONOPHENOLS

\begin{tabular}{|c|c|c|c|}
\hline \multirow[t]{2}{*}{ Compounds } & \multirow[t]{2}{*}{$\begin{array}{l}\text { Sodium } \\
\text { nitrite } \\
\text { treatment }\end{array}$} & \multicolumn{2}{|c|}{$\begin{array}{l}\text { DNA-breaking } \\
\text { activity after } \\
\text { incubation with } \\
\text { DMSO for }\end{array}$} \\
\hline & & 0 day & 5 days \\
\hline Sodium nitrite & - & - & - \\
\hline \multirow[t]{2}{*}{ Tyrosine } & - & - & - \\
\hline & + & - & + \\
\hline \multirow[t]{2}{*}{ Monoiodotyrosine } & - & - & - \\
\hline & + & - & + \\
\hline \multirow[t]{2}{*}{ Diiodotyrosine } & - & - & - \\
\hline & + & - & ++ \\
\hline \multirow[t]{2}{*}{ Thyronine } & - & - & - \\
\hline & + & - & + \\
\hline \multirow[t]{2}{*}{ Triiodothyronine } & - & - & - \\
\hline & + & - & - \\
\hline \multirow[t]{2}{*}{ Thyroxine } & - & - & - \\
\hline & + & - & - \\
\hline$o$-Nitrophenol & - & - & - \\
\hline$p$-Nitrophenol & - & - & - \\
\hline$p$-Nitrosophenol & - & - & + \\
\hline
\end{tabular}




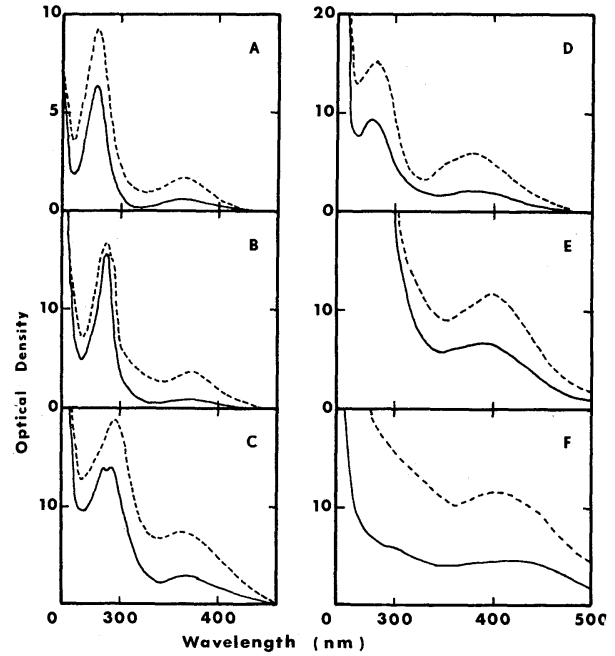

FIG. 1. UV and Visible Spectra of Monophenols Treated with $\mathrm{NaNO}_{2}$.

Reaction mixtures were incubated at $37^{\circ} \mathrm{C}$ for $1 \mathrm{hr} \mathrm{(-)}$ or $5 \mathrm{hr}$ (---). (A), tyrosine; (B), MIT; (C), DIT; (D), thyronine; $(\mathrm{E}), \mathrm{T}_{3} ;(\mathrm{F}), \mathrm{T}_{4}$.

activity immediately after dissolving in DMSO. After incubation of the products at $37^{\circ} \mathrm{C}$ for 5 days in DMSO, however, DNA-breaking activity was detected strongly in DIT treated with nitrite, and weakly in products obtained from tyrosine, MIT, and thyronine. $\mathrm{T}_{3}$ and $\mathrm{T}_{4}$ treated with nitrite and any of the starting materials (sodium nitrite and phenyl compounds) had no DNA-breaking activity, even after 5 days of incubation in DMSO. These results suggest that potent DNA-breaking substances produced by nitrite treatment are activated during incubation with DMSO.

To clarify the effects of solvents on the appearance of DNA-breaking activity, DIT treated with nitrite was dissolved in DMSO or dimethyl formamide (DMF), or suspended in water, ethanol, or acetone, and then incubated at $37^{\circ} \mathrm{C}$ for several days before using in the DNAbreaking reaction (Table II). In DMF solution, the activity appeared and then disappeared faster than in DMSO. The compound suspended in water, ethanol, or acetone had no activity during the 5 days of incubation.

Iodophenols are nitrated with nitrite in $100 \% \mathrm{AcOH}^{5)}$ Nitrosation of phenols with nitrite also occurs in aqueous solution. ${ }^{6)}$ Production of the potent DNA-breaking sub-
Table II. EFFects of Incubation Solvents ON THE DNA-BREAKING ACTIVITY OF DIT Treated With Sodium Nitrite

\begin{tabular}{|c|c|c|c|c|}
\hline \multirow{2}{*}{ Solvents } & \multicolumn{4}{|c|}{$\begin{array}{l}\text { DNA-breaking activity after } \\
\text { incubation for }\end{array}$} \\
\hline & 0 day & 1 day & 3 days & 5 days \\
\hline DMSO & - & + & ++ & $+t$ \\
\hline $\mathrm{DMF}$ & - & ++ & + & - \\
\hline Water & - & - & - & - \\
\hline Ethanol & - & - & - & - \\
\hline Acetone & - & - & - & - \\
\hline
\end{tabular}

stance derived from DIT was high in 25 and $50 \% \mathrm{AcOH}$, low in $1 \mathrm{~N} \mathrm{HCl}$ and $75 \% \mathrm{AcOH}$, and did not occur in $100 \%$ $\mathrm{AcOH}$ (data not shown). When two nitrophenols and a nitrosophenol dissolved in DMSO were used in the DNAbreaking reaction, activity was detected only in nitrosophenol incubated with DMSO for $\dot{5}$ days (Table I). These results suggest that the potent DNA-breaking substance is produced by nitrosation of DIT and activated in DMSO or DMF to cause DNA-breaking activity. DNA-breaking activity of the activated compound was detected only in the presence of $\mathrm{Cu}^{2+}$ and not in the presence of $\mathrm{Mn}^{2+}$, $\mathrm{Mg}^{2+}, \mathrm{Ni}^{2+}, \mathrm{Co}^{2+}, \mathrm{Fe}^{2+}$, or $\mathrm{Fe}^{2+}$, as seen in diphenols. ${ }^{7,8)}$

\section{REFERENCES}

1) K. Yamada, S. Shirahata, H. Murakami, K. Nishiyama, K. Shinohara and H. Omura, Agric. Biol. Chem., 49, 1423 (1985).

2) H. Murakami, K. Yamada, S. Shirahata, H. Nishiguchi, K. Shinohara and H. Omura, Agric. Biol. Chem., 42, 1019 (1978).

3) L. S. Kaplan and I. H. Goldberg, Biochemistry, 16, 479 (1977).

4) T. Andoh and T. Ide. Cancer Res., 32, 1230 (1972).

5) T. Zinke, J. Prakt. Chem., 61, 561 (1900).

6) K. Yamada, H. Murakami, S. Shirahata and H. Omura, Agric. Biol. Chem., 41, 2319 (1977).

7) H. Murakami, S. Shirahata, C. Hori, H. Yoshii, K. Yamada, K. Shinohara and H. Omura, Agric. Biol. Chem., 43, 1619 (1979).

8) S. Shirahata, H. Murakami, K. Yamada and H. Omura, Nippon Nôgeikagaku Kaishi, 56, 1027 (1982). 